\title{
Matematik uygulamaları dersine dair matematik öğretmenlerinin görüşleri
}

\author{
İbrahim Murat ÖDEN, Nazlı YILDIZ İKİKARDEŞ2,**

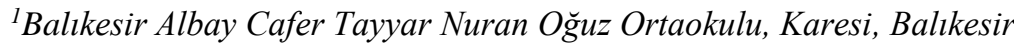 \\ ${ }^{2}$ Balıkesir Üniversitesi, Necatibey Eğitim Fakültesi, Matematik Eğitimi Anabilim Dall, Balıkesir
}

Geliş Tarihi (Received Date): 18.07.2020

Kabul Tarihi (Accepted Date): 30.09.2020

\section{$\ddot{O} z$}

Bu çalışma ile ortaokul matematik öğretmenlerinin 2012 yılından itibaren ögrretim programında seçmeli olarak bulunan matematik uygulamaları dersine (5.,6.,7. ve 8.sınıf düzeylerinde) dair fikirlerinin belirlenmesi, karşılaştıkları problemlerin ortaya çıkarılması ve çözüm önerilerinin alınması amaçlanmıştır. Çalışma, nitel ve nicel yöntemlerin birlikte yer aldı̆̆ karma şekilde desenlenmiştir. Araştırma, 2016-2017 bahar yarıyılında Balıkesir Altıeylül ve Karesi ilçelerindeki yedi farklı ortaokulda görev yapan 77 matematik öğretmeni ile gerçekleştirilmiştir. Araştırmanın başlangıcında ögretmenlere "Matematik Uygulamaları Dersine Dair Ögretmen Görüşleri” anketi uygulanmıştır. Veriler toplandıktan sonra SPSS (Statistical Package for the Social Sciences) kullanılarak analizi yapılmıştır. Araştırmanın sonraki aşamasında, dersin işlenişindeki aksaklıklarl ve bunlara ögretmenlerin sunduğu çözümleri belirlemek gayesiyle matematik ögretmenleriyle yarı yapılandırılmış görüşmeler, 77 öğretmenin içinden gelişigüzel seçilen yedi ögretmen ile yapılmıştır. Beş sorudan oluşan görüşme formu araştırmacılar tarafindan hazırlanmış olup geçerliği ve güvenirliği uzman görüşü ile sağlanmıştır. Görüşmeler sonucu ele geçen bilgiler, içerik analizi yöntemi kullanılarak çözümlenmiştir. Araştırmanın sonunda ögretmenler matematik uygulamaları dersinin faydalı ve gerekli olduğunu belirtilmişlerdir. Başkaca dersin işlenişinde karşılaşılan sorunlar ortaya çıkarılmış, bunlara çare olabilecek tavsiyeler verilmiştir.

Anahtar kelimeler: Matematik uygulamaları dersi, öğretmen görüşleri, seçmeli dersler, ortaokul matematik ögretim programı.

İbrahim Murat ÖDEN, imuratoden@hotmail.com, https://orcid.org/0000-0002-5789-1065

*Nazlı YILDIZ IKIKARDEŞ, nyildiz@balikesir.edu.tr, https://orcid.org/0000-0001-8756-8085 


\title{
Opinions of mathematics teachers about mathematics applications course
}

\begin{abstract}
With this study, it was aimed to determine the ideas of secondary school mathematics teachers about the Mathematics Applications course (at 5th, 6th, 7th and 8th grade levels), which has been included in the curriculum since 2012, to reveal the problems they encounter, and to get solution suggestions. The study was designed in a mixed way, where qualitative and quantitative methods coexisted. The research was conducted with 77 mathematics teachers working in seven different secondary schools in Ballkesir Altieylül and Karesi districts in the spring semester of 2016-2017. At the beginning of the study, a questionnaire of "Teacher Opinions About Mathematics Applications Course" was applied to the teachers. After the data were collected, analysis was done using SPSS (Statistical Package for the Social Sciences). In the next stage of the research, done semi-structured interviews with mathematics teachers with seven randomly selected in 77 teachers in order to determine the disruptions in the lesson and the solutions offered by the teachers. The interview form consisting of five questions was prepared by the researchers and its validity and reliability were ensured by expert opinion. The information obtained as a result of the interviews was analyzed using the content analysis method. At the end of the research, teachers stated that the mathematics applications course was useful and necessary. Also, the problems encountered in the course were revealed, and recommendations were given to remedy them.
\end{abstract}

Keywords: Mathematics applications course, teachers' opinions, elective course, secondary mathematics curriculum.

\section{Giriş}

Dünyamız sürekli bir gelişim içerisindedir ve gelişim sürecinin temel unsurları olan bilim, birey, toplum ve teknoloji için matematik olmazsa olmaz bir unsurdur. Matematik, bireyin iletişim kurabilme, genelleştirme yapabilme, yaratıcı ve bağımsız düşünebilme davranışlarını geliştirir. Bundan dolayı yaşam için çok önemli olan bu üst düzey davranışların gelişimini sağlayan matematiğin öğrenilmesi gereklidir [1].

Matematiği sadece okullarda okutulan bir ders olarak görmek hata olur. Matematik bireyin günlük yaşantısında karşılaşacağı birçok problemi çözmesini sağlayan bir öğretidir. Bundan dolayı matematik için sadece sayıları ve işlemleri anlatan bir ders tanımlamasını yapamayız. Matematik, gelişen ve karmaşıklaşan hayatta zorlukları aşmamızı sağlayan düşünme, ilişki kurma, akıl yürütme, tahmin yapma gibi becerilerimizi geliştiren bir disiplindir [2].

Günümüz dünyasında matematik kullanımı ve matematiği anlayabilme ihtiyacı artmaktadır. $\mathrm{Bu}$ değişen ve gelişen koşullarda artık matematik yeteneği gelişmiş bireylerin geleceklerini şekillendirmede daha fazla seçeneği olmaktadır. Bunun yanı sıra matematik eğitiminin değişen ve gelişen gereksinimler doğrultusunda yeniden, tekrar tekrar tasarlanması gerekmektedir [3]. 
Kalkınmayı hedefleyen ülkeler eğitime yatırım yapmalıdır. $\mathrm{Bu}$ yatırımlar doğrudan eğitimin niteliğini arttırmak hedefinde olmalıdır. Bu da güçlü eğitim programları sayesinde olur. Eğitim sisteminde ortaya çıkabilecek sorunlar bir ülkede izlenen milli eğitim politikasının geliştirilmesi ile aşılır. Ülkede yetiştirilecek bireylerin niteliği izlenen eğitim programları ile doğrudan alakalıdır [4].

Ülkemizde 2012-2013 yılından itibaren, gerçekleştirilen eğitim sistemi değişikliği $(4+4+4)$ ile birlikte ortaokullarda, matematik uygulamaları dersi seçmeli bir ders olarak okutulmaya başlanmıştır. Matematik uygulamaları dersinin uygulamaya konma amacı öğrencilerin zorunlu matematik dersini desteklemek ve daha üst seviye matematiksel problemler çözebilme tecrübesi yaşamalarıdır [5].

Matematik uygulamaları dersinin içeriği; günlük hayattan gerçek ve kurmaca problemler, diğer bilim alanlarından matematiksel problemler ve soyut matematiksel oyunlardan oluşmaktadır. Program, öğrencilerin sınıftaki yaşantılarında ağırlıklı olarak bireysel çalışma yerine grup çalışmasını, sınıf tartışmasını ve sunumlarını öngörmektedir. Öğrenciler, bu süreçte mantıklı yaklaşımları ve çözümleri ortaya çıkarmalı, öğretmen de bu derste doğru çözüme yönlendirmekten çok, öğrencilerin çözüm yollarını kendilerinin bulmalarına yardımcı olmalıdır. Böylece derste hem öğrencilerin matematiksel bilgi ve becerilerinin derinleşmesi hem de sosyal becerilerinin desteklenmesi amaçlanmaktadır [5].

$\mathrm{Bu}$ dersin genel amacı öğrencilerin matematiğe karşı olumlu tutum geliştirmesini sağlamaktır. Bunun için öğrencilere düzeylerine uygun şekilde matematiksel uygulamalar yaptırılır. Böylelikle onların matematiksel bilgi ve becerilerinin gelişmesi hedeflenir. Bu genel amacın üç bileşeni vardır:

- $\mathrm{Bu}$ ders sayesinde öğrencilerin gördüğü zorunlu matematik dersinin genel amaçları desteklenir. Öğrenciler matematiksel tecrübelerini problem çözerek çeşitlendirirler ve böylelikle matematiksel bilgilerini içselleştirirler.

- Öğrenciler matematik ile diğer disiplinler arasında ilişki kurarlar. Düşüncelerini matematiksel olarak çoklu gösterimlerle ifade ederler.

- Öğrenciler matematiği severler, problem çözebilmek için gereken sabrı ve çabayı gösterirler [6].

Matematiğin bir anlamda günlük hayata uyarlanması olarak yorumlanabilecek seçmeli matematik uygulamaları dersi, öğrencinin matematiği sevmesine, anlamasına ve ayrıca öğrencinin matematik dersine büyük katkı sağlayacaktır. Seçmeli matematik uygulamaları dersindeki problemlerin, bu bağlamda günlük hayatla ilişkilendirilmesi amaca hizmet edecektir. Dolayısıyla matematik öğretmenin rehberliğinde, öğrenciler; çözüm yollarını kendileri bulacak, matematiksel deneyimlerini problem çözerek zenginleştirecek ve matematiksel bilgilerini derinleştirme olanağına sahip olacaklardır. Bundan dolayı bu araştırma ile uygulayıcı olan öğretmenlerin yeni öğretim programı ile hayata geçen seçmeli matematik uygulamaları dersine yönelik görüşlerini belirlemek ve öğretmenlerin önerilerini sunmak amaçlanmıştır [7]. Bu amaca ulaşmak için aşağıdaki sorulara yanıt aranmıştır:

1. Matematik uygulamaları dersi öğretim programının kazanımlarına ilişkin öğretmen görüşleri cinsiyet, mesleki kıdem ve öğrenim durumlarına göre anlamlı olarak farklılık göstermekte midir? 
2. Matematik uygulamaları dersi öğretim programının içeriğine ilişkin öğretmen görüşleri cinsiyet, mesleki kıdem ve öğrenim durumlarına göre anlamlı olarak farklılık göstermekte midir?

3. Matematik uygulamaları dersi öğretim programının sürecine ilişkin öğretmen görüşleri cinsiyet, mesleki kıdem ve öğrenim durumlarına göre anlamlı olarak farklılık göstermekte midir?

4. Matematik uygulamaları dersi öğretim programının değerlendirmesine ilişkin öğretmen görüşleri cinsiyet, mesleki kıdem ve öğrenim durumlarına göre anlamlı olarak farklılık göstermekte midir?

5. Matematik uygulamaları dersi öğretim programının güçlü ve zayıf yönlerine ilişkin öğretmen görüşleri nelerdir?

6. Matematik uygulamaları dersi öğretim programının uygulanması sırasında karşılaşılan sorunların çözümüne ilişkin öğretmenlerin önerileri nelerdir?

\section{Yöntem}

\subsection{Araştırmanın modeli}

$\mathrm{Bu}$ araştırmanın modeli, nitel ve nicel araştırmanın bir arada kullanıldığ şeklindedir. Karma yöntem, nicel ve nitel verilerle çalışmanın güvenirliğini arttırırken geçerliliği de sağlamlaştırmaktadır [8]. Araştırmanın nicel boyutunda elde edilen verilere ulaşmak amacıyla tarama modeli kullanılmıştır. Tarama modelinde önemli olan, var olanı değiştirmeye kalkmadan gözleyebilmektir [9]. Nicel verilere ulaşmak amaciyla öğretmenlere "Matematik Uygulamaları Dersi Programına İlişkin Öğretmen Görüşleri Anketi" uygulanmış ve betimsel istatistikleri yapılarak öğretmenlerin görüşleri belirlenmiştir. Araştırmanın nitel boyutunda ise durum çalışması modeli benimsenmiş, veriler öğretmenlerle yapılan görüşmelerle elde edilmiştir.

\section{2. Çalışma grubu}

Araştırmanın çalışma grubunu, 2016-2017 öğretim yılında Balıkesir ili Altıeylül ve Karesi ilçelerinde bulunan 10 farklı ortaokulda görev yapmakta olan 77 matematik öğretmeni oluşturmaktadır. Araştırmada nicel verilerin elde edilmesinde tesadüfî örneklem kullanılmıştır. Araştırmada nicel verilerin elde edilmesi amacıyla anket 77 öğretmene ve araştırmada nitel verilerin elde edilmesi amacıyla yarı yapılandırılmış görüşme formu ise 77 öğretmen arasından tesadüfi seçilen 7 öğretmene uygulanmıştır.

\subsection{Veri toplama araçları}

Araştırmada Budak'ın (2011), bütününe dair iç tutarlılık katsayısı 0,95, ölçeğin alt boyutlarının Cronbach Alpha güvenirlik katsayıları ise içerik için 0,90, kazanımlar için 0,80 , öğretim süreci için 0,87 ve değerlendirme için 0,87 olarak hesaplanmış olan anket kullanılmıştır [10]. Ankette; öğretmenlerin program kazanımlarına yönelik görüşlerini ölçmek amacıyla 6 madde, programın içeriğgine yönelik görüşlerini ölçmek amaciyla 8 madde, programın sürecine yönelik görüşlerini ölçmek amacıyla 11 madde, programın değerlendirilmesine yönelik görüşlerini ölçmek amacıyla 7 madde olmak üzere toplam 32 madde yer almaktadır. Anketteki maddeler, "hiç katılmıyorum" seçeneğinden "kesinlikle katılıyorum" seçeneğine doğru 5 madde ile ölçeklendirilmiştir.

Öğretmenlere anket uygulandıktan sonra araştırmanın nitel verilerine ulaşmak amacı ile öğretmenlerle yarı yapılandırılmış görüşmeler "Matematik Uygulamaları Dersi Görüşme Formu" kullanılarak gerçekleştirilmiştir. Görüşme formunda; öğretmenlere matematik uygulamaları dersini kaçıncı sınıftaki öğrencilere verdiklerini, bu dersin 
öğrencilere katkısının olup olmadığını, bu dersi alan öğrencilerin derse karşı tutumlarının değişip değişmediğini, dersi işlerken yaşadıkları zorlukların olup olmadığını, varsa bu zorluklara çözüm önerilerinin neler olduğunu belirlemek amacı ile sorulmuş sorulara yer verilmiştir. Nitel araştırmalardaki geçerlik, araştırmacının araştırdığı olguyu olabildiğince tarafsız betimlemesi olarak tanımlanır [9]. Araştırmanın geçerliğinin sağlanması için veri toplama sürecinden önce iki uzman matematik öğretmeni ile görüşme test edilerek son hali verilen görüşme formu oluşturulmuştur.

\subsection{Veri toplama süreci}

Gerekli izinler alındıktan sonra araştırmacı tarafından tek tek okullara gidilerek "Matematik Uygulamaları Dersi Programına İlişkin Öğretmen Görüşleri Anketi” yazılı olarak matematik öğretmenlerine uygulanmıştır. Anket uygulanmadan önce araştırmacı tarafından her öğretmene anket tanıtılmış ve nasıl cevaplanacağ okunmuştur. Katılımcılara anketleri doldurmaları için 15-20 dakika süre verilmiştir. Çalışmadaki "Matematik Uygulamaları Dersi Görüşme Formu" kullanılarak anketi dolduran öğretmenler arasından tesadüfen seçilen 7 matematik öğretmeni ile görüşme yapılmıştır. Görüşmeler 30 ile 50 dakika arasında değişen sürelerde gerçekleştirilmiştir. Görüşmelerde öğretmenlerden izin alınarak ses kayıt cihazı kullanılmış, daha sonra bu ses kayıtlarından elde edilen veriler yazıya dökülmüştür.

\subsection{Verilerin analizi}

Matematik öğretmenlerinin demografik özellikleri ile matematik uygulamaları dersinin programının kazanımlarına, sürecine, içeriğine ve değerlendirmesine yönelik görüşlerinin ölçülmesi için "Matematik Uygulamaları Dersi Programına İlişkin Öğretmen Görüşleri Anketi" uygulandıktan sonra elde edilen veriler SPSS programı yardımıyla analiz edilmiştir. Cinsiyet ve öğrenim durumunun analizlerinde bağımsız örneklem için t-testi, kıdem durumu incelemesi için ise varyans analizi (ANOVA) kullanılmıştır. Ankette öğrenim durumu 4 kategoriden oluşmakta iken ön lisans ve doktora seçenekleri örneklemde yer almadığı için bu durum iki gruplu olarak analiz edilmiştir.

Görüşme formundan yararlanarak öğretmenlerle yüz yüze yapılan görüşmelerin kayıtları, hiç bir değişiklik yapılmadan olduğu gibi yazıya aktarılmıştır. Yazıya dökülen bu veriler, üzerinde kodlamalar yapılarak metin üzerinde işaretlenmiştir. Birbiri ile ilişkili olan kodlar bir araya getirilerek ortak temalar araştırmacılar tarafından oluşturulmuştur. Ayrıca güvenirliği belirlemek amacıyla veriler bir uzman tarafından kodlanmıştır. Kodlama yapanlar arası uyum "Güvenirlik = Görüş Birliği / (Görüş Birliği + Görüş Ayrılığı) x 100” ile hesaplanarak \%83 olarak bulunmuştur. Güvenirlik için iki farklı kodlama yapan kişinin uyumu için \%70'in üstündeki değerler yeterlidir [11]. Görüşme formunun uygulandığı öğretmenlere numaralar verilmiş ve alıntılar bu numaralar kullanılarak yapılmıştır. Görüşmelerden elde edilen veriler, içerik analizi yapılarak çözümlenmiştir.

\section{Bulgular}

$\mathrm{Bu}$ kısımda, araştırmanın verilerinin analizinden elde edilen bulgular yer almaktadır.

\subsection{Birinci soruya ilişkin bulgular}

"Matematik uygulamaları dersi öğretim programının kazanımlarına ilişkin öğretmen görüşleri cinsiyet, mesleki kıdem ve öğrenim durumlarına göre anlamlı olarak farklılık 
göstermekte midir?" sorusuna yanıt almak için öğretmenlere uygulanan anketten elde edilen verilerin analizinden ortaya çıkan bulgulara yer verilmiştir.

Tablo 1. Öğretmenlerin cinsiyetlerine göre matematik uygulamaları dersi öğretim programının kazanımlarına yönelik görüşleri.

\begin{tabular}{|c|c|c|c|c|c|c|c|}
\hline & \multicolumn{7}{|c|}{ Ortalama Eşitliği için T Testi } \\
\hline & \multirow[t]{2}{*}{$\mathrm{t}$} & \multirow[t]{2}{*}{ df } & \multirow{2}{*}{$\begin{array}{c}\text { Sig. } \\
\text { (2-tailed) }\end{array}$} & \multirow{2}{*}{$\begin{array}{l}\text { Ortalama } \\
\text { Fark }\end{array}$} & \multirow{2}{*}{$\begin{array}{c}\text { Standart } \\
\text { Hata Fark1 }\end{array}$} & \multicolumn{2}{|c|}{$\begin{array}{c}\text { 95\% Farkın } \\
\text { Güven Aralı̆g } 1\end{array}$} \\
\hline & & & & & & Alt & Üst \\
\hline $\begin{array}{l}\text { Varsayılan Eşit } \\
\text { Varyanslar }\end{array}$ & ,189 & 75 &, 851 &, 02432 & , 12890 & -23246 & ,28111 \\
\hline $\begin{array}{l}\text { Varsayılmayan Eşit } \\
\text { Varyanslar }\end{array}$ & ,188 & 72,729 &, 852 & 02432 & , 12949 & -23380 & ,28244 \\
\hline
\end{tabular}

Tablo 1'de görüldüğü gibi $(\mathrm{t}(75)=0,189, \quad \mathrm{p}>0,05)$ matematik öğretmenlerinin cinsiyetlerine göre matematik uygulamaları dersi öğretim programının kazanımlarına yönelik görüşlerinde anlamlı farklılık yoktur.

Tablo 2. Öğretmenlerin öğrenim durumlarına göre matematik uygulamaları dersi öğretim programının kazanımlarına yönelik görüşleri.

\begin{tabular}{|c|c|c|c|c|c|c|c|}
\hline & \multicolumn{7}{|c|}{ Ortalama Eşitliği için T Testi } \\
\hline & \multirow[t]{2}{*}{$\mathrm{t}$} & \multirow[t]{2}{*}{ df } & \multirow{2}{*}{$\begin{array}{c}\text { Sig. } \\
\text { (2-tailed) }\end{array}$} & \multirow{2}{*}{$\begin{array}{l}\text { Ortalama } \\
\text { Fark }\end{array}$} & \multirow{2}{*}{$\begin{array}{c}\text { Standart } \\
\text { Hata Fark1 }\end{array}$} & \multicolumn{2}{|c|}{$\begin{array}{c}\text { 95\% Farkın Güven } \\
\text { Aralığ1 }\end{array}$} \\
\hline & & & & & & Alt & Üst \\
\hline Varsayılan Eşit & & & & & & & \\
\hline Varyanslar & $-1,655$ & 75 &, 102 &,- 36429 & ,22009 & -80273 &, 07416 \\
\hline Varsayılmayan Eşit & & & & & & & \\
\hline Varyanslar & $-2,366$ & 9,210 & , 042 &,- 36429 & , 15397 &,- 71138 &,- 01719 \\
\hline
\end{tabular}

Tablo 2'de görüldüğü üzere $(\mathrm{t}(75)=1,655, \mathrm{p}>0,05)$ matematik öğretmenlerinin eğitim durumlarına göre programın kazanımlarına yönelik görüşlerinde anlamlı farklılık yoktur.

Tablo 3. Öğretmenlerin kıdem durumlarına göre matematik uygulamaları dersi öğretim programının kazanımlarına yönelik görüşleri (I).

\begin{tabular}{|c|c|c|c|c|c|c|}
\hline & & Kareler Toplamı & $\mathrm{df}$ & Kareler Ortalaması & $\mathrm{F}$ & Sig. \\
\hline & Gruplar Arası & 4,691 & 5 & ,938 & \multirow{3}{*}{3,456} & \multirow{3}{*}{, 007} \\
\hline $\begin{array}{c}\text { Göre } \\
\text { Öğgretmenlerin } \\
\text { Kazanımlara }\end{array}$ & Gruplar İçi & 19,273 & 71 & ,271 & & \\
\hline $\begin{array}{l}\text { Yonellk } \\
\text { Görüşleri }\end{array}$ & Toplam & 23,964 & 76 & & & \\
\hline
\end{tabular}

Tablo 3'ten anlaşılacağı $(F(5 ; 76)=3,456, p<0,05)$ matematik öğretmenlerinin kıdeme bağlı olarak program kazanımlarına yönelik görüşlerinde istatistiksel olarak anlamlı farklılık vardır. Matematik öğretmenlerinin kıdeme bağlı olarak programın kazanımlarına yönelik görüşlerinde istatistiksel olarak anlamlı farkın hangi kıdem yılları 
arasında olduğunu belirlemek için yapılan Post-Hoc Scheffe analizlerinin sonuçları Tablo 4'te verilmiştir.

Tablo 4. Öğretmenlerin kıdem durumlarına göre matematik uygulamaları dersi öğretim programının kazanımlarına yönelik görüşleri (II).

\begin{tabular}{|c|c|c|c|c|c|c|c|}
\hline \multirow[t]{2}{*}{ (I)Kidem } & \multirow[t]{2}{*}{ (J)Kidem } & \multirow[t]{2}{*}{ Y11 } & \multirow{2}{*}{$\begin{array}{c}\text { Ortalama } \\
\text { Fark1 }\end{array}$} & \multirow{2}{*}{$\begin{array}{c}\text { Standart } \\
\text { Hata }\end{array}$} & \multirow[t]{2}{*}{ Sig. } & \multicolumn{2}{|c|}{ \%95 Güvenilir Aralık } \\
\hline & & & & & & Alt limit & Üst limit \\
\hline \multirow[t]{15}{*}{ Scheffe } & $1-5$ & $6-10$ & ,31481 & ,28800 & ,944 &,- 6711 & 1,3007 \\
\hline & & $11-15$ & ,05000 & ,28057 & 1,000 &,- 9105 & 1,0105 \\
\hline & & $16-20$ & , 13333 & ,30823 & 999 &,- 9218 & 1,1885 \\
\hline & & $21-25$ & 67593, & ,28800 & ,367 &,- 3100 & 1,6618 \\
\hline & & 26 ve üstü & 25000 & ,45121 & ,997 & $-1,2946$ & 1,7946 \\
\hline & $6-10$ & $11-15$ &,- 26481 & ,16105 & ,745 &,- 8161 & ,2865 \\
\hline & & $16-20$ & 18148 & 20549, & ,978 &,- 8849 & ,5219 \\
\hline & & $21-25$ & 36111 & , 17367 & ,509 &,- 2334 & ,9556 \\
\hline & & 26 ve üstü &,- 06481 & ,38286 & 1,000 & $-1,3942$ & 1,2645 \\
\hline & $11-15$ & $16-20$ & ,08333 & ,19494 & ,999 &,- 5840 & ,7507 \\
\hline & & $21-25$ & ,62593 & ,16105 & ,016 & ,0746 & 1,1772 \\
\hline & & 26 ve üstü & 20000 & ,38286 & ,998 & $-1,1106$ & 1,5106 \\
\hline & $16-20$ & $21-25$ & ,54259 & ,20549 & ,237 &,- 1608 & 1,2460 \\
\hline & & 26 ve üstü &, 11667 & ,40357 & 1,000 & $-1,2648$ & 1,4982 \\
\hline & $21-25$ & 26 ve üstü &,- 42593 & ,38834 & ,943 & $-1,7553$ & ,9034 \\
\hline
\end{tabular}

Tablo 4'ten anlaşılacağı gibi 11-15 yıl arası çalışmış öğretmenler ile 21-25 yıl arası çalışmış öğretmenlerin görüşleri arasında farklılık olduğu tespit edilmiştir. 11-15 y1l arası çalışanların görüşleri daha olumlu olduğu görülmüştür.

\section{2. İkinci soruya ilişkin bulgular}

"Matematik uygulamaları dersi öğretim programının içeriğine ilişkin öğretmen görüşleri cinsiyet, mesleki kıdem ve öğrenim durumlarına göre anlamlı olarak farklılık göstermekte midir?" sorusuna yanıt almak için öğretmenlere uygulanan anketten elde edilen verilerin analizinden ortaya çıkan bulgulara yer verilmiştir.

Tablo 5. Öğretmenlerin cinsiyetlerine göre matematik uygulamaları dersi öğretim programının içeriğine yönelik görüşleri.

\begin{tabular}{|c|c|c|c|c|c|c|c|}
\hline & \multicolumn{7}{|c|}{ Ortalama Eşitliği için T Testi } \\
\hline & \multirow[t]{2}{*}{$\mathrm{t}$} & \multirow[t]{2}{*}{$\mathrm{df}$} & \multirow{2}{*}{$\begin{array}{c}\text { Sig. } \\
\text { (2-tailed) }\end{array}$} & \multirow{2}{*}{$\begin{array}{l}\text { Ortalama } \\
\text { Fark }\end{array}$} & \multirow{2}{*}{$\begin{array}{c}\text { Standart } \\
\text { Hata Fark1 }\end{array}$} & \multicolumn{2}{|c|}{$\begin{array}{c}\text { 95\% Farkın } \\
\text { Güven Aralığ } 1\end{array}$} \\
\hline & & & & & & Alt & Üst \\
\hline $\begin{array}{l}\text { Varsayılan Eşit } \\
\text { Varyanslar }\end{array}$ & 1,201 & 75 & ,233 & ,15726 & , 13089 &,- 10349 & ,41801 \\
\hline $\begin{array}{l}\text { Varsayılmayan Eşit } \\
\text { Varyanslar }\end{array}$ & 1,203 & 74,868 & ,233 & ,15726 & , 13070 &,- 10311 & ,41764 \\
\hline
\end{tabular}

Tablo 5'de görüldüğü gibi $(\mathrm{t}(75)=1,201, \quad \mathrm{p}>0,05)$ matematik öğretmenlerinin cinsiyetlerine göre program içeriğine yönelik görüşlerinde anlamlı farklılık bulunmamaktadır. 
Tablo 6. Öğretmenlerin öğrenim durumlarına göre matematik uygulamaları dersi öğretim programının içeriğine yönelik görüşleri.

\begin{tabular}{|c|c|c|c|c|c|c|c|}
\hline & \multicolumn{7}{|c|}{ Ortalama Eşitliği için T Testi } \\
\hline & \multirow[t]{2}{*}{$\mathrm{t}$} & \multirow[t]{2}{*}{ df } & \multirow{2}{*}{$\begin{array}{c}\text { Sig. } \\
\text { (2-tailed) }\end{array}$} & \multirow{2}{*}{$\begin{array}{l}\text { Ortalama } \\
\text { Fark }\end{array}$} & \multirow{2}{*}{$\begin{array}{c}\text { Standart } \\
\text { Hata Fark1 }\end{array}$} & \multicolumn{2}{|c|}{$\begin{array}{c}\text { 95\% Farkın } \\
\text { Güven Aralığ1 }\end{array}$} \\
\hline & & & & & & Alt & Üst \\
\hline $\begin{array}{l}\text { Varsayılan Eşit } \\
\text { Varyanslar }\end{array}$ & $-1,638$ & 75 &, 106 &,- 36964 & ,22566 &,- 81918 & ,07989 \\
\hline $\begin{array}{c}\text { Varsayılmayan Eşit } \\
\text { Varyanslar }\end{array}$ & $-4,738$ & 66,859 & 000 &,- 36964 & ,07801 & -52536 & 21393 \\
\hline
\end{tabular}

Tablo 6'dan $(\mathrm{t}(66,859)=4,738, \mathrm{p}<0,05)$ matematik öğretmenlerinin eğitim durumlarına göre program içeriğine yönelik görüşlerinde anlamlı farklılık vardır. Yüksek lisans eğitimi almış öğretmenlerin içerik ile ilgili maddelerden aldıkları puanların ortalamaları, lisans mezunu öğretmenlerin ortalamalarından istatistiksel açıdan anlamlı seviyede yüksektir.

Tablo 7. Öğretmenlerin kıdem durumlarına göre matematik uygulamaları dersi öğretim programının içeriğine yönelik görüşleri (I).

\begin{tabular}{|c|c|c|c|c|c|c|}
\hline & & Kareler Toplam 1 & df & Kareler Ortalaması & $\mathrm{F}$ & Sig. \\
\hline & Gruplar Arası & 6,334 & 5 & 1,267 & & \\
\hline Kidemlerine & & & & & 4,774 & ,001 \\
\hline $\begin{array}{l}\text { Öğretmenlerin } \\
\text { Kazanımlara }\end{array}$ & Gruplar İçi & 18,840 & 71 & 265 & & \\
\hline $\begin{array}{c}\text { Yönelik } \\
\text { Görüssleri }\end{array}$ & Toplam & 25,173 & 76 & & & \\
\hline
\end{tabular}

Tablo 7'ye göre $(\mathrm{F}(5 ; 76)=4,774, \mathrm{p}<0,05)$ matematik öğretmenlerinin kıdeme bağl1 olarak programın içeriğine yönelik görüşlerinde istatistiksel olarak anlamlı farklılık bulunmaktadır. Matematik öğretmenlerinin kıdeme bağlı olarak programın içeriğine yönelik görüşlerinde istatistiksel olarak anlamlı farkın hangi kıdem yılları arasında olduğunu belirlemek için yapılan Post-Hoc Scheffe analizleri yapılmıştır ve sonuçları Tablo 8'de verilmiştir.

Tablo 8. Öğretmenlerin kıdem durumlarına göre matematik uygulamaları dersi öğretim programının içeriğine yönelik görüşleri (II).

\begin{tabular}{rlrccccc}
\hline (I)Kidem & (J)Kidem & Y1l & Ortalama & \multicolumn{2}{c}{ Standart } & Sig. & \multicolumn{2}{c}{ \%95 Güvenilir Aralik } \\
& & & Fark1 & Hata & & Alt limit & Üst limit \\
\hline Scheffe & $\mathbf{1 - 5}$ & $6-10$ &, 14391 &, 28474 &, 998 &,- 8254 & 1,1240 \\
& & $11-15$ &, 28125 &, 27740 &, 959 &,- 6683 & 1,2308 \\
& & $16-20$ &, 25625 &, 30475 &, 982 &,- 7870 & 1,2995 \\
& $\mathbf{2 1 - 2 5}$ & $\mathbf{, 8 3 6 8 1}$ & $\mathbf{, 2 8 4 7 4}$ & $\mathbf{, 1 3 9}$ & $\mathbf{- , 1 3 7 9}$ & $\mathbf{1 , 8 1 1 5}$ \\
& & 26 ve üstü &,- 21875 &, 44611 &, 999 & $-1,7459$ & 1,3084 \\
\cline { 2 - 7 } & $11-15$ &, 13194 &, 15923 &, 983 &,- 4131 &, 6770 \\
& $16-20$ &, 10694 &, 20317 &, 998 &,- 5885 &, 8024 \\
& $\mathbf{6 - 1 0}$ & $\mathbf{2 1 - 2 5}$ & $\mathbf{, 6 8 7 5 0}$ & $\mathbf{, 1 7 1 7 1}$ & $\mathbf{, 0 1 1}$ & $\mathbf{, 0 9 9 7}$ & $\mathbf{1 , 2 7 5 3}$ \\
& 26 ve üstü &,- 36806 &, 38395 &, 968 & $-1,6824$ &, 9463 \\
\hline & $16-20$ &,- 02500 &, 19274 & 1,000 &,- 6848 &, 6348 \\
& $\mathbf{1 1 - 1 5}$ & $\mathbf{2 1 - 2 5}$ & $\mathbf{, 5 5 5 5 6}$ & $\mathbf{, 1 5 9 2 3}$ & $\mathbf{, 0 4 3}$ & $\mathbf{, 0 1 0 5}$ & $\mathbf{1 , 1 0 0 6}$ \\
& & 26 ve üstü &,- 50000 &, 37853 &, 881 & $-1,7958$ &, 7958 \\
\hline
\end{tabular}


Tablo 8. (Devam1).

\begin{tabular}{|c|c|c|c|c|c|c|}
\hline $16-20$ & $\begin{array}{r}21-25 \\
26 \text { ve üstü }\end{array}$ & $\begin{array}{c}, 58056 \\
-, 47500\end{array}$ & $\begin{array}{l}\text {,20317 } \\
\text {,39901 }\end{array}$ & $\begin{array}{l}, 162 \\
, 921\end{array}$ & $\begin{array}{c}-, 1149 \\
-1,8409\end{array}$ & $\begin{array}{c}1,2760 \\
, 8909\end{array}$ \\
\hline $21-25$ & 26 ve üstü & $-1,05556$ & 38395 & ,197 & $-2,3699$ & 2588 \\
\hline
\end{tabular}

Tablo 8'de görüldüğü gibi 21-25 yıl arası çalışmış öğretmenler ile 1-5 yıl arası çalışmış öğretmenlerin görüşleri arasında farklılık olduğu tespit edilmiş ve 1-5 yıl arası çalışan öğretmenlerin görüşlerinin daha olumlu bulunmuştur. 21-25 y1l arası çalışmış öğretmenler ile 6-10 yıl arası çalışmış öğretmenlerin görüşleri arasında farklılık tespit edilmiş ve 6-10 yıl arası çalışmış öğretmenlerin görüşleri daha olumludur. Son olarak 21-25 yıl arası çalışmış öğretmenler ile 11-15 yıl arası çalışmış öğretmenlerin görüşleri arasında farklılık olduğu tespit edilmiş ve 11-15 yıl arası çalışmış öğretmenlerin görüşlerinin daha olumlu olduğu sonucu çıkmıştır.

\section{3. Üçüncü soruya ilişkin bulgular}

"Matematik uygulamaları dersi öğretim programının sürecine ilişkin öğretmen görüşleri cinsiyet, mesleki kıdem ve öğrenim durumlarına göre anlamlı olarak farklılık göstermekte midir?" sorusuna yanıt almak için öğretmenlere uygulanan anketten elde edilen verilerin analizinden ortaya çıkan bulgulara yer verilmiştir.

Tablo 9. Öğretmenlerin cinsiyetlerine göre matematik uygulamaları dersi öğretim programının sürecine yönelik görüşleri.

\begin{tabular}{|c|c|c|c|c|c|c|c|}
\hline & \multicolumn{7}{|c|}{ Ortalama Eşitliği için T Testi } \\
\hline & \multirow[t]{2}{*}{$\mathrm{t}$} & \multirow[t]{2}{*}{ df } & \multirow{2}{*}{$\begin{array}{c}\text { Sig. } \\
\text { (2-tailed) }\end{array}$} & \multirow{2}{*}{$\begin{array}{l}\text { Ortalama } \\
\text { Fark }\end{array}$} & \multirow{2}{*}{$\begin{array}{c}\text { Standart } \\
\text { Hata Fark1 }\end{array}$} & \multicolumn{2}{|c|}{$\begin{array}{c}\text { 95\% Farkın } \\
\text { Güven Aralığ1 }\end{array}$} \\
\hline & & & & & & Alt & Üst \\
\hline $\begin{array}{c}\text { Varsayılan Eşit } \\
\text { Varyanslar }\end{array}$ & 2,263 & 75 &, 027 & ,28968 & , 12800 &, 03470 &, 54466 \\
\hline $\begin{array}{c}\text { Varsayılmayan Eşit } \\
\text { Varyanslar }\end{array}$ & 2,260 & 73,997 & 027 & ,28968 & , 12819 & ,03427 &, 54510 \\
\hline
\end{tabular}

Tablo 9'a göre $(\mathrm{t}(75)=2,263, \mathrm{p}<0,05)$ matematik öğretmenlerin cinsiyetlerine göre program sürecine yönelik görüşlerinde anlamlı farklılık görülmektedir. Erkek öğretmenlerin süreç ile ilgili maddelerden aldıkları puanların ortalaması, kadın öğretmenlerin ortalamasından istatistiksel açıdan anlamlı seviyede fazladır.

Tablo 10. Öğretmenlerin öğrenim durumlarına göre matematik uygulamaları dersi öğretim programının sürecine yönelik görüşleri.

\begin{tabular}{|c|c|c|c|c|c|c|c|}
\hline & \multicolumn{7}{|c|}{ Ortalama Eşitliği için T Testi } \\
\hline & \multirow[t]{2}{*}{$\mathrm{t}$} & \multirow[t]{2}{*}{ df } & \multirow{2}{*}{$\begin{array}{c}\text { Sig. } \\
\text { (2-tailed) }\end{array}$} & \multirow{2}{*}{$\begin{array}{l}\text { Ortalama } \\
\text { Fark }\end{array}$} & \multirow{2}{*}{$\begin{array}{c}\text { Standart } \\
\text { Hata Fark1 }\end{array}$} & \multicolumn{2}{|c|}{$\begin{array}{c}\text { 95\% Farkın Güven } \\
\text { Aralığ } 1\end{array}$} \\
\hline & & & & & & Alt & Üst \\
\hline Varsayılan Eşit & & & & & & & \\
\hline Varyanslar & $-1,638$ & 75 &, 106 &,- 36964 & ,22566 &,- 81918 & ,07989 \\
\hline Varsayılmayan Eşit & & & & & & & \\
\hline Varyanslar & $-4,738$ & 66,859 &, 000 &,- 36964 & ,07801 &,- 52536 &,- 21393 \\
\hline
\end{tabular}


Tablo 10'a göre $(\mathrm{t}(75)=1,638, \mathrm{p}>0,05)$ matematik öğretmenlerinin öğrenim durumlarına göre program sürecine yönelik görüşlerinde anlamlı farklılık bulunmamaktadır.

Tablo 11. Öğretmenlerin kıdemlerine göre matematik uygulamaları dersi öğretim programının sürecine yönelik görüşleri (I).

\begin{tabular}{ccccccc}
\hline & & Kareler Toplam1 & df & Kareler Ortalamas1 & F & Sig. \\
\hline & Gruplar Arası & 4,966 & 5 & ,993 & \multirow{3}{*}{,480 } & ,007 \\
\cline { 2 - 5 } $\begin{array}{c}\text { Kidemlerine } \\
\text { Göre }\end{array}$ & Gruplar İçi & 20,264 & 71 &, 285 & & \\
$\begin{array}{c}\text { Öğretmenlerin } \\
\text { Kazanımlara } \\
\text { Yönelik } \\
\text { Görüşleri }\end{array}$ & Toplam & 25,230 & 76 & & & \\
\cline { 2 - 5 } & & & & & & \\
\hline
\end{tabular}

Tablo 11'e göre $(\mathrm{F}(5 ; 76)=3,480, \mathrm{p}<0,05)$ matematik öğretmenlerinin k1deme bağl1 olarak programın sürecine yönelik görüşlerinde istatistiksel olarak anlamlı farklılık vardır. Bu farkın hangi kıdem yılları arasında olduğunu belirlemek için Post-Hoc Scheffe analizleri yapılmıştır.

Tablo 12. Öğretmenlerin kıdemlerine göre matematik uygulamaları dersi öğretim programının sürecine yönelik görüşleri (II).

\begin{tabular}{|c|c|c|c|c|c|c|c|}
\hline \multirow[t]{2}{*}{ (I)Kidem } & \multirow{2}{*}{ (J)Kidem } & \multirow[t]{2}{*}{ Y11 } & \multirow{2}{*}{$\begin{array}{l}\text { Ortalama } \\
\text { Fark1 }\end{array}$} & \multirow{2}{*}{$\begin{array}{l}\text { Standart } \\
\text { Hata }\end{array}$} & \multirow{2}{*}{ Sig. } & \multicolumn{2}{|c|}{ \%95 Güvenilir Aralık } \\
\hline & & & & & & Alt limit & Üst limit \\
\hline \multirow[t]{15}{*}{ Scheffe } & $1-5$ & $6-10$ &,- 11111 & ,29531 & 1,000 & $-1,1220$ & ,8998 \\
\hline & & $11-15$ &,- 32909 & 28769 & ,932 & $-1,3139$ & 6557 \\
\hline & & $16-20$ &,- 28182 & ,31606 & ,977 & $-1,3638$ & 8001 \\
\hline & & $21-25$ & 28283 & 29531 & 968 &,- 7281 & 1,2937 \\
\hline & & 26 ve üstü &,- 68182 & , 46266 & 823 & $-2,2656$ & ,9020 \\
\hline & $6-10$ & $11-15$ &,- 21798 & , 16514 & ,882 &,- 7833 & ,3473 \\
\hline & & $16-20$ &,- 17071 & 21070 & ,985 &,- 8920 & ,5506 \\
\hline & & $21-25$ & ,39394 & , 17808 & ,437 &,- 2157 & 1,0035 \\
\hline & & 26 ve üstü &,- 57071 & 39820 & 840 & $-1,9338$ & ,7924 \\
\hline & $11-15$ & $16-20$ & ,04727 & , 19989 & 1,000 &,- 6370 & ,7315 \\
\hline & & 21-25 & ,61192 & ,16514 & ,025 & ,0466 & 1,1772 \\
\hline & & 26 ve üstü &,- 35273 & ,39258 & ,976 & $-1,6966$ & ,9912 \\
\hline & $16-20$ & $21-25$ & ,56465 & ,21070 & ,222 &,- 1566 & 1,2859 \\
\hline & & 26 ve üstü &,- 40000 & ,41382 & 967 & $-1,8166$ & 1,0166 \\
\hline & $21-25$ & 26 ve üstü &,- 96465 &, 39820 & 331 & $-2,3278$ & 3985 \\
\hline
\end{tabular}

Tablo 12'ye göre 11-15 yıl arası çalışmış öğretmenler ile 21-25 y1l arası çalışmış öğretmenlerin görüşleri arasında anlamlı farklılık olduğu bulunmuştur ve 11-15 y1l arası çalışanların görüşleri daha olumludur.

\subsection{Dördüncü soruya ilişkin bulgular}

"Matematik uygulamaları dersi öğretim programının değerlendirmesine ilişkin öğretmen görüşleri cinsiyet, mesleki kıdem ve öğrenim durumlarına göre anlamlı olarak farklılık göstermekte midir?" sorusuna yanıt almak için öğretmenlere uygulanan anketten elde edilen verilerin analizinden ortaya çıkan bulgulara yer verilmiştir. 
Tablo 13. Öğretmenlerin cinsiyetlerine göre matematik uygulamaları dersi öğretim programının değerlendirmesine yönelik görüşleri.

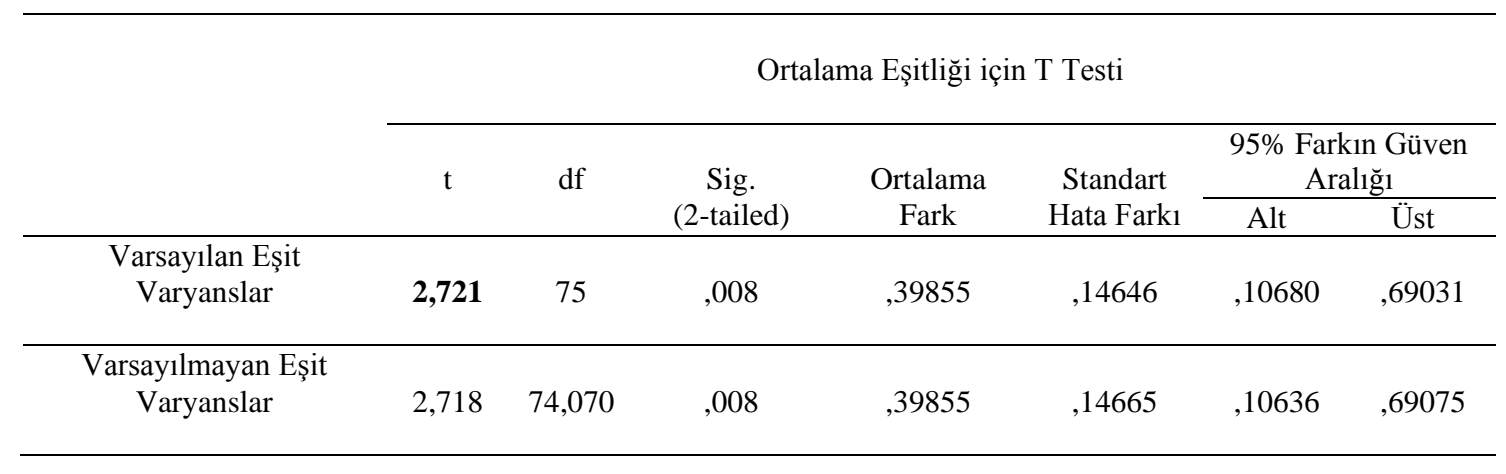

Tablo 13'te $(\mathrm{t}(75)=2,721, \mathrm{p}<0,05)$ matematik öğretmenlerinin cinsiyetlerine göre programın değerlendirme basamağına yönelik görüşlerinde anlamlı farklılık bulunmaktadır. Kadınların değerlendirme ile ilgili maddelerden aldıkları puanların ortalaması, erkeklerin ortalamasından istatistiksel açıdan anlamlı seviyede fazladır.

Tablo 14. Öğretmenlerin öğrenim durumlarına göre matematik uygulamaları dersi öğretim programının değerlendirmesine yönelik görüşleri.

\begin{tabular}{|c|c|c|c|c|c|c|c|}
\hline & \multicolumn{7}{|c|}{ Ortalama Eşitliği için T Testi } \\
\hline & \multirow[t]{2}{*}{$\mathrm{t}$} & \multirow[t]{2}{*}{ df } & \multirow{2}{*}{$\begin{array}{c}\text { Sig. } \\
\text { (2-tailed) }\end{array}$} & \multirow{2}{*}{$\begin{array}{l}\text { Ortalama } \\
\text { Fark }\end{array}$} & \multirow{2}{*}{$\begin{array}{l}\text { Standart } \\
\text { Hata Fark1 }\end{array}$} & \multicolumn{2}{|c|}{$\begin{array}{l}\text { 95\% Farkın Güven } \\
\text { Aralığ } 1\end{array}$} \\
\hline & & & & & & Alt & Üst \\
\hline Varsayılan Eşit & & & & & & & \\
\hline Varyanslar & $-1,197$ & 75 & ,235 &,- 31633 & ,26429 &,- 84282 & ,21016 \\
\hline Varsayılmayan Eşit & & & & & & & \\
\hline Varyanslar & $-1,400$ & 7,868 & ,200 &,- 31633 & 22601 &,- 83903 & 20638 \\
\hline
\end{tabular}

Tablo 14'te verilenlere göre $(\mathrm{t}(75)=1,197, \mathrm{p}>0,05)$ matematik öğretmenlerinin öğrenim durumlarına göre değerlendirme basamağına yönelik görüşlerinde anlamlı bir farklılık bulunmamaktadir.

Tablo 15. Öğretmenlerin kıdem durumlarına göre matematik uygulamaları dersi öğretim programının değerlendirmesine yönelik görüşleri (I).

\begin{tabular}{ccccccc}
\hline & & $\begin{array}{c}\text { Kareler } \\
\text { Toplamı }\end{array}$ & df & $\begin{array}{c}\text { Kareler } \\
\text { Ortalaması }\end{array}$ & F & Sig. \\
\hline $\begin{array}{c}\text { Kidemlerine } \\
\text { Göre }\end{array}$ & Gruplar Arası & 5,710 & 5 & 1,142 & & \\
\cline { 2 - 5 } $\begin{array}{c}\text { Öğretmenlerin } \\
\text { değerlendirmeye } \\
\text { Yönelik } \\
\text { Görüşleri }\end{array}$ & Gruplar İçi & 28,264 & 71 & $\mathbf{2 , 8 6 9}$ & & ,020 \\
\cline { 2 - 5 } & Toplam & 33,973 & 76 & & \\
\hline
\end{tabular}

Tablo 15'e göre $(\mathrm{F}(5 ; 76)=2,869, \mathrm{p}<0,05)$ matematik öğretmenlerinin kıdem durumlarına göre programın değerlendirme basamağına yönelik görüşlerinde istatistiksel olarak anlamlı farklılık bulunmaktadır. Farkın hangi kıdem yılları arasında olduğunu 
belirlemek için yapılan Post-Hoc Scheffe analizleri yapılmış ve sonuçları Tablo 16 ' da verilmiştir.

Tablo 16. Öğretmenlerin kıdemlerine göre matematik uygulamaları dersi öğretim programının değerlendirmesine yönelik görüşleri (II).

\begin{tabular}{|c|c|c|c|c|c|c|c|}
\hline \multirow[t]{2}{*}{ (I)Kidem } & \multirow[t]{2}{*}{ (J)Kidem } & \multirow[t]{2}{*}{ Y11 } & \multirow{2}{*}{$\begin{array}{c}\text { Ortalama } \\
\text { Fark1 }\end{array}$} & \multirow{2}{*}{$\begin{array}{c}\text { Standart } \\
\text { Hata }\end{array}$} & \multirow[t]{2}{*}{ Sig. } & \multicolumn{2}{|c|}{ \%95 Güvenilir Aralık } \\
\hline & & & & & & Alt limit & Üst limit \\
\hline \multirow{15}{*}{ Scheffe } & $1-5$ & $6-10$ & ,63492 & ,34876 & ,653 &,- 5590 & 1,8288 \\
\hline & & $11-15$ & ,33143 & ,33977 & ,965 &,- 8317 & 1,4945 \\
\hline & & $16-20$ & 67143 & ,37327 &, 665 &,- 6063 & 1,9492 \\
\hline & & $21-25$ & ,77778 & ,34876 &, 427 &,- 4161 & 1,9717 \\
\hline & & 26 ve üstü &,- 50000 & ,54641 &, 974 & $-2,3705$ & 1,3705 \\
\hline & $6-10$ & $11-15$ &,- 30349 & , 19504 &, 787 &,- 9711 & ,3642 \\
\hline & & $16-20$ & 03651 & ,24885 & 1,000 &,- 8153 &, 8884 \\
\hline & & $21-25$ &, 44635 & ,21031 & ,993 &,- 5771 & ,8628 \\
\hline & & 26 ve üstü &,- 83143 & ,47027 &, 335 & $-2,7448$ & ,4749 \\
\hline & $11-15$ & $16-20$ & ,34000 & ,23608 &, 837 &,- 4681 & 1,1481 \\
\hline & & $21-25$ & ,44635 & , 19504 &, 397 & ,2213 & 1,1140 \\
\hline & & 26 ve üstü &,- 83143 & ,46364 & 668 & $-2,4186$ &, 7557 \\
\hline & $16-20$ & $21-25$ & , 10635 & ,24885 & ,999 &,- 7455 & ,9582 \\
\hline & & 26 ve üstü & $-1,17143$ & , 48872 &, 343 & $-2,8444$ &, 5016 \\
\hline & $21-25$ & 26 ve üstü & $-1,27778$ & ,47027 & ,208 & $-2,8876$ & ,3321 \\
\hline
\end{tabular}

Tablo 16'ya göre 26 yıl ve üstü çalışmış öğretmenler ile 21-25 yıl arası çalışmış öğretmenlerin görüşleri arasında farklılık olduğu tespit edilmiş ve 21-25 y1l aras1 çalışanların görüşlerinin daha olumlu olduğu sonucu ortaya çıkmıştır.

\subsection{Beşinci soruya ilişkin bulgular}

"Matematik uygulamaları dersi öğretim programının güçlü ve zayıf yönlerine ilişkin öğretmen görüşleri nelerdir?" sorusuna yanıt almak için öğretmenlerle yapılan yarı yapılandırılmış görüşmelerin analizinden elde edilen bulgulara ve görüşmelerden alıntılara yer verilmiştir. Görüşme sırasında öğretmenlere yöneltilen sorular ve verilen yanıtların kategori edilmiş hali tablolar halinde verilmiştir.

Tablo 17. Öğretmen görüşme formu soru kategori tablosu.

\begin{tabular}{|c|c|}
\hline $\begin{array}{l}\text { Soru 1: "Hangi sınıfın/sınıfların seçmeli matematik uygulamaları dersine } \\
\text { giriyorsunuz?" }\end{array}$ & Öğretmenler \\
\hline 5. sinif & Ö2,Ö6,Ö7 \\
\hline 6. sinif & Ö3,Ö6,Ö7 \\
\hline 7.sinif & Ö1,Ö2,Ö3 \\
\hline 8.sinif & Ö4,Ö3 \\
\hline $\begin{array}{l}\text { Soru 2: "Seçmeli matematik uygulamaları dersinin öğrencilere ne gibi katkıları } \\
\text { olduğunu düşünüyorsunuz" }\end{array}$ & Öğretmenler \\
\hline Konu tekrarı açısından olumlu & Ö1,Ö2,Ö3,Ö4 \\
\hline Kazanımların kavratılması açısından olumlu & Ö1 \\
\hline Soru çözüldüğ̈̈ için olumlu & Ö1,Ö2,Ö4 \\
\hline Eğlenceli olduğu için olumlu & Ö3,Ö5,Ö6 \\
\hline Matematiği sevdirdiği için olumlu & Ö3,Ö5,Ö6 \\
\hline Öğrencilerin matematik becerilerini arttırdığı için olumlu & Ö6 \\
\hline Öğrencilerin negatif tutumu nedeniyle olumsuz & Ö7 \\
\hline $\begin{array}{l}\text { Soru 3: "Seçmeli matematik uygulamaları dersi sayesinde öğrencilerinizin } \\
\text { matematik dersine karşı tutumu değişti mi? Olumlu mu yoksa olumsuz yönde mi } \\
\text { değişme oldu?" }\end{array}$ & Öğretmenler \\
\hline Olumlu yönde değişti & Ö1,Ö3,Ö4 \\
\hline Her hangi bir değişiklik gözlemlemedim & Ö2,Ö5,Ö6,Ö7 \\
\hline
\end{tabular}


Tablo 17. (Devam1).

\begin{tabular}{ll}
\hline $\begin{array}{l}\text { Soru 4: “Seçmeli matematik uygulamaları dersinin işleniş̧iyle ilgili yaşadığınız } \\
\text { zorluklar nelerdir?’” }\end{array}$ & Öğretmenler \\
\hline Öğrenci kitaplarının olmaması & Ö1,Ö5 \\
5. sını öğretmen kitabı öğrenci seviyesinin çok üstünde & Ö2 \\
Öğrencilerin olumsuz tutumu & Ö2,Ö3,Ö4,Ö5,Ö7 \\
\hline Soru 5: "Bu zorlukların çözümü/çözümleri sizce nedir ?”” & Öğretmenler \\
\hline Kitap basıllp öğrencilere dağıtılabilir & Ö1,Ö2,Ö3 \\
Öğretmen daha etkin olabilir & Ö2 \\
Öğretmenler matematik dersine girdiği öğrencilerin seçmeli derslerine girebilirler & Ö3,Ö4 \\
Dersi gerçekten isteyen öğrencilerin seçmesi sağlanabilir & Ö6 \\
Ders kaldırılmalı & Ö7 \\
\hline
\end{tabular}

Matematik uygulamaları dersini veren öğretmenlerden 6 tanesi dersin öğrencilerin gelişimi açısından olumlu, 1 tanesi ise olumsuz olduğunu düşünmektedir. Bazı öğretmenlerin görüşleri:

"Matematik uygulamaları dersi sayesinde öğrenci anlamadı̆̆ı konuları tekrar dinleme şansı yakalıyor. Akademik başarısı yüksek ögrencilerde ise isteyerek seçildiği için oyun, etkinlik gibi faaliyetlerle sevdiği dersi daha da etkili olarak zevk alarak tamamlyor.(Ö3)"

“Öğrencilerin matematiği sevmesine faydası olduğunu düşünüyorum. Öğrencinin matematiği sevmemesindeki en önemli sebep yapamamasıdır. Ders sayesinde matematik becerilerinin artacă̆ını düşünüyorum.(Ö6)"

"Pek bir katkısı olduğunu düşünmüyorum. Dersin işlenmesini istemiyorlar. Dolayıslyla bu tutumlarl ders yapmayı engelliyor.(Ö7)"

Matematik öğretmenlerinin üçü öğrencilerin tutumlarının olumlu yönde değiştiğini dördü ise öğrencilerin tutumlarında herhangi bir değişim gözlenmediğini ifade etmişlerdir. Bazı öğretmenlerin görüşleri:

"Aslında olumlu değiştiğini düşünüyorum. Çünkü daha eğlenceli geçiyor. Matematik dersinde konuyu daha hızl işlememiz gerekirken bu derste daha ağır ders işleyebiliyoruz. Birde öğrenciler farklı farklı sınıflardan karıştıkları için onlar içinde değişiklik olumlu oluyor. Farkl ögretmenlerin girmesi de onlar için değişik bir ortam oluyor. Sonuç olarak bazl ögrenciler için iyi oluyor, matematikle ilgisi olmayan ögrenciler için olumlu olduğu söylenemez.(Ö1)”

"Bazı ögrencilerin dersle alakası yok bu nedenle onların tutumu değişmiyor. Ancak dersle ilgilenen ögrenciler için olumlu yönde değişim oluyor.(Ö5)"

Görüşülen matematik öğretmenlerinden iki tanesi öğrenci kitabının olmadığını, biri 5. Sınıf kitabının öğrencilerin kavrayamayacağı kadar zor olduğunu beşi ise derse katılan öğrencilerin olumsuz tutumunun problem yarattığını ifade etmişlerdir. Bazı öğretmenlerin görüssleri:

"Kitabımızın olmaması bizim için bir zorluk oluyor. Biz kendimiz bir şeyler yapmaya çalışıyoruz. Çocuklara dağıtılan gerçek bir kitabımız olsa daha etkin işlenebilir. (Ö1)” 
"Daha önce çalıştığım okulları düşünerek şunu söyleyebilirim. 2 çeşit uygulama var. Küçük okullarda ögretmen girdiği sınıfa seçmeli matematik dersine de giriyor ve dersine devam ediyordu. Bazen işlediğimiz konuya devam ediyorduk. Programda geri kalmışsak telafi ediyorduk. Bol soru çözüyorduk. Seçmeli matematik kitabındaki etkinlikleri uygulamaya çalışlyorduk. Bununla ilgili bir eleştiri de getirmek istiyorum. Seçmeli matematik uygulamaları ders kitabının seviyesi ögrencilerin seviyesinin çok üstünde. Kitabın uygulatması zor görünüyor. Kitap ögrencilere dağıtılsa bile çözmek için boşluk ayrllamamış. Etkinliklerin bazlları 2 ders saatinde tamamlanamıyor. Kalabalık çok şubeli okullarda öğrenciler farklı sınıflardan toplanıyorlar. Genel olarak severek ve isteyerek katılıyorlar. Bazı öğrenciler ise dersi boş ders gibi düşünüyorlar. Ders işlemek istemiyorlar. Bu ögrenciler dersin düzenini işleyişini bozuyorlar. (Ö2)"

\subsection{Altıncı soruya ilişkin bulgular}

"Matematik uygulamaları dersi öğretim programının uygulanması sırasında karşılaşılan sorunların çözümüne ilişkin öğretmenlerin önerileri nelerdir?” sorusuna yanıt almak için öğretmenlerle yapılan yarı yapılandırılmış görüşmelerin analizinden elde edilen bulgulara ve görüşmelerden alıntılara yer verilmiştir.

“Öğretmen sinıf düzenini sağlamaları ögrencilere sevdirmeli. Kaynak kitap düzenlenip daha kullanışlı hale getirilmeli.(Ö2)"

"Bu derste seviye sinıflarının olması bazı öğrenciye konu anlatımına yönelmek adına, bazı ögrenciye ise etkin yöntemlerle pekiştirmek adına daha yararlı olabilecĕgi düşüncesineyim. Ayrıca dersine girmiş olduğunuz sınıfların seçmeli dersini anlamanız iletişim adına daha etkili oluyor.(Ö3)”

"Seçmeli dersi öğrencilerin velileri seçiyor. Öğrenci istemediği halde bu dersi seçiyor. Dolayısıla hiçbir şey yapmak istemiyor.(Ö6)”

“Ders kaldırılmalı.(Ö7)”

\section{Sonuçlar ve tartışma}

$\mathrm{Bu}$ çalışma sayesinde matematik uygulamaları dersini veren öğretmenlerin ders hakkındaki görüş ve önerileri ortaya çıkarılmıştır. Matematik uygulamaları dersi öğretim programının kazanımlar, içerik, süreç ve değerlendirme açısından öğretmen görüşleri cinsiyet, mesleki kıdem ve öğrenim durumlarına göre araştırılmıştır.

Matematik öğretmenlerinin, matematik uygulamaları dersi programının kazanımlarına yönelik görüşlerinde; kıdem durumlarına göre, program içeriğine yönelik görüşlerinde; eğitim seviyelerine ve kıdem durumlarına göre, program sürecine yönelik görüşlerinde; cinsiyete ve kıdeme bağlı olarak, programın değerlendirme basamağında; cinsiyete ve k1dem durumuna göre farkl1lıklar olduğu tespit edilmiştir.

Araştırmada görüşme yapılan öğretmenlerin üçü 5. Sınıflarda, üçü 6. Sınıflarda, üçü 7. Sınıflarda ikisi ise 8. Sınıflarda seçmeli matematik uygulamaları dersine girmektedir. Bunun yanında daha önceden tüm öğretmenlerin her sınıf düzeyinde bu derse yönelik tecrübeleri mevcuttur. 
Öğretmenlerin büyük çoğunluğu seçmeli matematik uygulamaları dersinin öğrencilere katkıs1 olduğunu düşünmektedirler. Görüşme yapılan öğretmenlerden dört tanesi dersin konu tekrarına, üçü soru çözümüne, üçü dersin eğlenceli hale gelmesine, üçü matematiği sevme noktasında, biri matematik becerilerini arttırma konusunda, biri kazanımların kavratılmasına yardımcı olmasına, biri ise öğrencinin matematiğe karşı negatif tutumunun kırılması yönünde katkıları olduğunu belirtmişlerdir. 2016 yılında Akay, Çırakoğlu ve H. Yanar'ın yaptıkları çalışmada ortaokul 5. ve 6. Sınıf öğrenci ve öğretmenlerinin seçmeli derslere ilişkin görüşleri alınmıştır. Seçmeli derslerin seçimin aşamasında ağırlıklı olarak dış etkenlerin veya sağlanacak yararın göz önünde alındığı ifade edilmiştir. Derslerin içeriğine ilişkin olumlu ve olumsuz görüşlerin birbirine yakın olduğu ortaya çıkarılmıştır. Derslerin yararları konusunda öğretmen ve öğrenci görüşlerinde farklılıklar olduğu saptanmıştır [12].

Matematik uygulamaları dersinde yaşanılan zorluklar sorulduğunda öğretmenlerin büyük çoğunluğu öğrencilerin olumsuz tutumundan yakınmışlardır. Bunun nedeninin genellikle ders seçimini ailelerin yaptığını öğrencilerin dersi istemedikleri halde seçmek zorunda olduklarını ifade etmişlerdir. Benzer olarak Ataman (2015) çalışmasında öğretmen görüşlerine göre ailelerin, dersin içeriğinden yeterince haberdar olmadan, fazladan matematik çalışılacağ 1 düşüncesiyle bu dersi 5. sınıftaki öğrencilerinin yerine ebeveynlerin seçtikleri bulgusuna yer vermiştir [13]. Eyiol'un 2019 yılında yaptığ çalışmasında ise sınıfların grup çalışmasına uygun olarak tasarlanmadığı ve fiziksel ortamın programın etkililiğini olumsuz yönde etkilediği sonucuna ulaşılmıştır. Özellikle değişen sınav sisteminin etkisiyle öğretmen ve öğrenciler tarafından dersin gerekli görüldüğü, dersin seçiminde öğrencilerin kararlarında özgür olamadıkları, çoğunlukla sınıfın ortak kararına uymak durumunda kaldıkları sonucuna ulaşılmıştır [14].

Öğretmenler matematik uygulamaları ders kitabının ve gerekli materyallerin bulunmadığını belirtmişlerdir. Çoban ve Erdoğan'ın yaptıkları çalışmada da öğretmenlerin etkinliklerin gerektirdiği materyalleri ulaşmada sorunlarla karşılaştıkları ifade edilmiştir [15].

Görüşmeye katılan öğretmenlerden biri, matematik uygulamaları dersinin özellikle 5. Sınıf kazanımlarının öğrencilerin seviyesinin üstünde olduğunu ifade etmiştir. Çelikel ve Yelken'in çalışmasında ise öğretmenler matematik uygulamaları dersi öğretim programına ilişkin olarak, programda yer alan etkinliklerin öğrenci seviyesine daha uygun ve fiziki imkânlar ölçüsünde uygulanabilir olmasını önermişlerdir [16]. Çoban ve Erdoğan ise öğretmenlerin matematik uygulamaları 5. Sınıf müfredatındaki problemleri öğrencilerin seviyesinin üzerinde buldukları sonucuna varmışlardır [15]. Ataman'ın çalışmasında ise öğretmenlerin seçmeli matematik uygulamaları dersinin öğrencilerin düzeyine uygunluğu konusunda görüşlerinin "kararsızım" düzeyinde olduğunu ve öğretmenlere göre öğretmen kılavuz kitabının olmamasının ders işlenmesini zorlaştırdığı ortaya konmuştur [13].

Bu çalışmada görüşü alınan öğretmenlerin tümü, her ders seviyesinde kitap basılarak öğrencilere dağıtılmasını önermişlerdir. Mevcut durumda 5.Sınıfların ders kitabı bulunmakta, bu kitaptan da sadece 1 adet okullara gönderilmektedir. Öğretmenler fotokopi çekerek veya etkinliği öğrencilerin defterlerine yazdırarak dersi işlemektedirler. Bir etkinlik öğrencilerin defterlerine yazdırılmak istendiğinde bu işlem bir ders saati sürmektedir. Fotokopi ile çoğaltılınca ise malzeme sıkıntısı yaşanmaktadır. Yaşanan bu tür sorunların giderilmesi için Milli Eğitim Bakanlığı tarafından her okula, 
her öğrenciye, her seviyede kitap basılarak gönderilmelidir. Etkinlik kitabı mutlaka açık, anlaşılır ve öğrenci seviyesine uygun olarak hazırlanması önerilmektedir.

Seçmeli matematik uygulamaları dersinin matematik dersine büyük katkısı olacağı veli tarafından düşünüldüğünden, bu derse büyük ilgi olmakta ve sonuç olarak sınıfların kalabalık olması birçok sıkıntıyı doğurmaktadır. Boyraz ve Güçlü'nün 2018'de yayımlanan çalışmasında da öğretmenler programın amacı doğrultusunda gidildiğinde dersin eğlenceli bir ders olduğunu ve öğrencilerin matematiğe karşı tutumlarının olumlu yönde etkilediğini belirtmişlerdir. Matematik uygulamaları dersi seçilirken yoğun bir ilgi olduğunu fakat değerlendirmenin notla yapılmasını olumsuz bulduklarını ifade etmişlerdir. Ayrıca öğretmenler, sınıfların kalabalık olmasının uygulamalı bir dersin işlenişini zorlaştırdığını dile getirmişlerdir [17].

Öğrencinin matematik dersini veren öğretmen ile matematik uygulamaları dersini veren öğretmenin, aynı öğretmen olması, öğrencinin matematik eksiğinin giderilmesi açısından daha yararlı olacağı düşünülmektedir. Dolayısıyla derslerin verimli olması açısından okul idarelerinin zorunda kalmadıkça seçmeli matematik uygulamaları dersine, öğrencinin matematik dersi öğretmenini görevlendirmesi öğretmenlerce önerilmektedir.

Seçmeli matematik uygulamaları dersinde yer alan etkinlikler, özellikle de 5. Sınıf ve 6. Sınıf öğrencilerinin okuyarak uygulayabileceği tarzda etkinlikler değildir. Bu sebeple dersi veren öğretmenin daha etkin rol üstlenmesi, etkinliği vereceği örneklerle anlaşılır hale getirmesi gerekmektedir.

Seçmeli matematik uygulamaları dersini almak isteyen öğrencilerin seçilmesine özen gösterilmelidir. Öğretmenler, derse karşı ilgisiz ve isteksiz öğrencilerin bu dersi aslında istemediklerini, ailelerinin isteği üzerine zorunlu seçtiklerini ifade etmektedirler. Ebeveynler çocuklarının matematik dersinde daha başarılı olmasını istemekte ve çocuklarını seçmeli matematik uygulamaları dersine yönlendirmektedirler. Sonuçta zorla bu dersi seçen öğrenci, derse karşı olumsuz tavır göstermekte ve verimli bir çalışma gerçekleşememektedir. Bu nedenledir ki okul yöneticileri; velileri, çocuklarına ders seçiminde fikrini sormaları ve zorla ders seçtirmemeleri konusunda uyarmalıdırlar. Ayrıca seçmeli matematik uygulamaları dersini alan öğrencilerin sınıflandırılması yapılırken öğrencilerin matematik dersi not ortalamaları temel alınarak seviye grupları oluşturulabilir. Böylece sınıf içi seviye farkından oluşan sınıf içi kopukluklar önlenebilir. Ayrıca dersin seçimine müdahale eden velinin, dersin işlenişine farkında olmadan yarattığı olumsuz etkinin azaltılmasına yararlı olacağı düşünülmektedir.

\section{Kaynaklar}

[1] Çağlar, G., Yapılandırmacı Yaklaşımın Matematik Öğretimine (İlköğretim 7.sınıflarda) Etkisi. Yüksek Lisans Tezi, Beykent Üniversitesi, Sosyal Bilimler Enstitüsü, Ankara, (2010).

[2] Umay, A., Matematiksel muhakeme yeteneği, Hacettepe Üniversitesi Eğitim Fakültesi Dergisi, 24, 234-243, (2003).

[3] MEB, İlköğretim matematik 6-8. sınıflar öğretim programı kitabı, Talim ve Terbiye Kurulu Başkanlığı, Ankara, (2005). 
[4] Sarıer, Y., Altıncı sınıf matematik öğretmenlerinin matematik dersi öğretim programına ilişkin görüşleri. Yüksek Lisans Tezi, Eskişehir Osmangazi Üniversitesi, Sosyal Bilimler Enstitüsü, Eskişehir, (2007).

[5] MEB, Ortaokul ve İmam Hatip Ortaokulu Matematik Uygulamaları Dersi (5, 6, 7 ve 8. Sınıflar) Öğretim Programı, Talim ve Terbiye Kurulu Başkanlığı, Ankara, (2012).

[6] MEB, İlköğretim matematik 5-8. sınıflar öğretim programı kitabı, Talim ve Terbiye Kurulu Başkanlığı, Ankara, (2013).

[7] Öden, İ. M., Ortaokul Matematik Öğretmenlerinin Seçmeli Matematik Uygulamaları Dersine İlişkin Görüşleri. Yüksek Lisans Tezi, Balıkesir Üniversitesi, Fen Bilimleri Enstitüsü, Balıkesir, (2019).

[8] Balcı, A., Sosyal bilimlerde araştırma, yöntem, teknik ve ilkeler, Ankara: Pegem A Yayıncilik, (2010).

[9] Karasar, N., Bilimsel Araştırma Yöntemleri, Ankara : Nobel Yayınları, (2005).

[10] Budak, M., 2005 İlköğretim Matematik Dersi 6-8. Sinıflar Öğretim Programına İlişkin Öğretmen Görüşleri. Yüksek Lisans Tezi, Erzincan Üniversitesi, Fen Bilimleri Enstitüsü, Erzincan, (2011).

[11] Akay, Y., Çırakoğlu, M. ve H.Yanar, B., Elementary Education Online, İlköğretim Online, 15(1), 1-22, (2016).

[12] Ataman, E., Ortaokul Matematik Uygulamaları Dersi Etkinliklerinin Öğretmen Görüşlerine Göre İncelenmesi. Yüksek Lisans Tezi, Gazi Üniversitesi, Eğitim Bilimleri Enstitüsü, Ankara, (2015).

[13] Eyiol, K., Ö., Ortaokul Matematik Uygulamaları Öğretim Programının Eisner'in Eğitsel Eleştiri Modeline Göre Değerlendirilmesi. Yüksek Lisans Tezi, Pamukkale Üniversitesi, Eğitim Bilimleri Enstitüsü, Denizli, (2019).

[14] Çoban, F. N. ve Erdoğan, A., Ortaokul Öğretmenlerinin Matematik Uygulamaları Dersinde Karşılaştıkları Sorunlar, Turkish Journal of Computer and Mathematics Education, 4(3), 242-258, (2013).

[15] Çelikel, F. ve Yelken, T.Y., Ortaokul Matematik Uygulamaları Dersi Öğretim Programının Uygulanmasına İlişkin Öğretmen ve Öğrenci Görüşleri, Alanya Alaaddin Keykubad Üniversitesi Sosyal Bilimler Dergisi/The Journal Of Social Science, Y1l: 4, Say1: 13, Ağustos 2017, 623-633, (2016).

[16] Boyraz, H. ve Güçlü, M., Ortaokul Matematik Uygulamaları Dersinde Karşılaşılan Zorluklar (Kayseri ili örneği). Uluslar arası Sosyal Araştırmalar Dergisi / The Journal of International Social Research, Cilt: 11, Say1: 55, Şubat 2018, http://dx.doi.org/10.17719/jisr.20185537228, (2018).

[17] Altun, M., Eğitim fakülteleri ve ilköğretim öğretmenleri için matematik öğretimi, Bursa: Aktüel Yayıncılık, (2005).

[18] Demirel, Ö., Kuramdan uygulamaya eğitimde program geliştirme, Ankara: Pegem A Yayıncilık, (1999).

[19] Olkun, S., İlköğretimde etkili matematik öğretimi için ipuçları, İlköğretmen Dergisi, 5, 31-35, (2007).

[20] Küçükahmet, L., Konu alanı ders kitabı incelemesi, Ankara: Nobel Yayın Dağıtım, (2004).

[21] Altun, M., Matematik öğretimi, Bursa: Alfa Yayın, (1998).

[22] Erdem, A. R., ve Genç, G., Ortaokul beşinci sınıfta seçmeli "matematik uygulamaları" dersini seçen öğrencilerin derse ilişkin görüşleri, Eğitimde Nitel Araştırmalar Dergisi - Journal of Qualitative Research in Education, 2(2), 10-26, (2014). 
[23] Göktaş, Ö., Matematik Öğretmenlerinin 5. Sınıf Matematik Dersi Öğretim Programına İlişkin Görüşleri. Dumlupınar Üniversitesi Sosyal Bilimler Dergisi / Dumlupınar University Journal of Social Sciences, 41. Say1 Temmuz 2014 / Number 41 July 2014 (2014).

[24] Kaplan A., Öztürk M. ve Doruk M., Matematik Uygulamaları Dersine Yönelik Beklenti Ölçeği: Geçerlik ve Güvenirlik Çalışması, Erzincan Üniversitesi Eğitim Fakültesi Dergisi, Cilt-Say1:16-2 (2014).

[25] Karagözoğlu, N., Ortaokul 5. Sinıflarda Tercih Edilen Seçmeli Dersler ve Tercih Nedenlerinin Öğrenci ve Veli Görüşlerine Göre Değerlendirilmesi, Pegem Ĕgitim ve Öğretim Dergisi, 5(1), 69-94, (2015).

[26] Karasar, N., Bilimsel araştırma yöntemleri, Ankara : Nobel Yayınları, (2005).

[27] Yıldırım A. ve Şimşek H., Nitel araştırma yöntemleri, Ankara: Seçkin Yayınc1lik, (2003).

[28] Büyüköztürk, Ş., Çakmak, E., Akgün, Ö. E., Karadeniz, Ş. ve Demirel, F., Bilimsel Araştırma Yöntemleri, Ankara: Pegem A Yayıncılık , (2008).

[29] Baykul, Y., İköğretim matematik öğretimi (1-5. Sınıflar), Ankara: An1 Yayıncilik, (1999).

[30] Keşan C., Coşar M. Ç. ve Erkuş Y., Matematik Uygulamaları Dersini Seçen Ortaokul Öğrencilerinin Derse İlişkin Görüşleri, Dokuz Eylül Üniversitesi Eğitim Bilimleri Enstitüsü Batı Anadolu Eğitim Bilimleri Dergisi ISSN 1308 - 8971 Cilt: 07, Say1: 14, 2016, 33 - 44 (2016).

[31] Özdal, S. ve Karataş, H., Beşinci Sınıf Matematik Dersi Öğretim Programına Yönelik Öğretmen Görüşleri, Eğitim ve Öğretim Araştırmaları Dergisi Journal of Research in Education and Teaching, Ağustos 2015 Cilt:4 Sayı:3 (2015).

[32] Taş, B.S., İlköğretim 6, 7 ve 8. Sinıflar "Seçmeli Ders Programlarının" Öğretmen ve Öğrenci Görüşleri Doğrultusunda Değerlendirilmesi. Yüksek Lisans Tezi, Çukurova Üniversitesi, Sosyal Bilimler Enstitüsü, Adana (2004).

[33] Taşpınar, M., Yeni İlköğretim 6. Sınıf Matematik Programının Ölçme Değerlendirme Kısmının Öğrenci Görüşleri Doğrultusunda İncelenmesi, Uludağ Üniversitesi Eğitim Fakültesi Dergisi, 22 (2): 551-572 (2009).

[34] Varış, F., Eğitimde program geliştirme, teori ve teknikler, Ankara: Alkım Yayınları (1996).

[35] Yenilmez, K., ve Duman, A., İlköğretimde matematik başarısını etkileyen faktörlere ilişkin öğrenci görüşler, Türkiye Manas Üniversitesi Sosyal Bilimler Dergisi, 19, 251-269 (2008).

[36] Yıldırım, S., İlköğretim I. Kademe Matematik Dersi Öğretim Programı'nın Kazanımlar Boyutunun Öğretmen Görüşlerine Göre Değerlendirilmesi. Yüksek Lisans Tezi, Onsekiz Mart Üniversitesi, Sosyal Bilimler Enstitüsü, Çanakkale (2009). 